\title{
Hafta İçi Uygulanan Destekleme ve Yetiştirme Kurslarına İlişkin Öğrenci Görüşleri: Fenomenolojik Bir Çalışma*
}

Ahmet Keskin 1

Type/Tür:

Research/Araştırma

Received/Geliş Tarihi: December

2/2 Aralık 2019

Accepted/Kabul Tarihi: April 9/9

Nisan 2020

Page numbers/Sayfa No: $820-844$

Corresponding

Author/İletişimden Sorumlu

Yazar:

enderkazak81@hotmail.com

\section{$\checkmark$ iThenticate}

This paper was checked for plagiarism using iThenticate during the preview process and before publication. / Bu çalışma ön inceleme sürecinde ve yayımlanmadan önce iThenticate yazılımı ile taranmıştır.

Copyright $@ 2017$ by Cumhuriyet University, Faculty of Education. All rights reserved.

\section{Ender Kazak ${ }^{2}$}

\section{Öz}

Bu çalışmanın amacı, Türkiye'de, 2014-2015 eğitim öğretim yılından itibaren uygulanmaya başlanan ve 2018-2019 eğitim öğretim yılı itibari ile yaklaşık olarak 10 milyon öğrenci, 500 bin öğretmen ve 10 bin yönetici ile eğitim üst yapılanmasını doğrudan etkileyen destekleme ve yetiştirme kurslarının (DYK) hafta içi uygulanmasına ilişkin öğrencilerin görüşlerini ortaya koymaktır. Araştırma, nitel araştırma yöntemlerinden betimsel fenomenoloji deseninde tasarlanmıştır. Araştırmanın çalışma grubunu, 20182019 eğitim öğretim yılı II. döneminde Düzce ilinde bir kamu ortaokulunda hafta içi destekleme ve yetiştirme kurslarına katılan otuz beş öğrenci oluşturmaktadır. Veriler, yarı yapılandırılmış görüşme tekniği kullanılarak toplanmış, verilerin çözümlenmesinde içerik analizi tekniği kullanılmıştır. Araştırma sonunda, öğrencilerin kursları; ders ve sınav başarısını artırmak, derslerde anlaşılmayan konuları daha iyi anlayabilmek, daha çok bilgi öğrenmek, ders ve konu tekrarı yapmak amacıyla tercih ettikleri tespit edilmiştir. Kursların, öğrencilerin akademik başarılarını ve motivasyonlarını $\operatorname{artırdığı;~planlı~ve~programlı~}$ çalışma becerisi kazandırdığı ve sosyalleşmelerine katkı sağladığı diğer tespitler arasındadır. Kursların kalitesinin artırılması için öğrenci önerileri değerlendirildiğinde, hafta içi DYK saatlerinin yeniden düzenlenmesi, kurs başlangıcında teneffüs süresinin uzun tutularak öğrencilerin beslenme ihtiyaçlarının giderilmesi, DYK'da temel dersler (Türkçe, Matematik, Fen Bilimleri, Sosyal Bilimler) dışında spor ve sanat etkinliklerinin de uygulanabilmesi gerektiği görüşleri öne çıkmıştır. Araştırmada ortaya çıkan sonuçların, başta Milli Eğitim Bakanlığı olmak üzere kurslarla ilgili tüm paydaşlara yol gösterici olacağı düşünülmektedir.

Anahtar Kelimeler: Destekleme ve yetiştirme kursu, öğrenci, ortaokul, fırsat eşitliği, fenomenoloji

\section{Suggested APA Citation/Önerilen APA Atıf Biçimi:}

Keskin, A. \& Kazak, E. (2020). Hafta içi uygulanan destekleme ve yetiştirme kurslarına ilişkin öğrenci görüşleri: Fenomenolojik bir çalışma. Cumhuriyet International Journal of Education, 9(3), 820844. http://dx.doi.org/10.30703/cije.654250 .

\footnotetext{
*Bu çalışma, 2. Eğitimde Yeni Arayışlar Kongresi’nde sözlü bildiri olarak sunulmuştur.

1 Öğretmen, Milli Eğitim Bakanlığı, Düzce/Türkiye

Teacher, Ministry of National Education, Düzce/Turkey

e-mail: duzcelikeskin@hotmail.com ORCID ID: orcid.org/0000-0001-8221-638X

2 Dr. Öğretim Üyesi, Düzce Üniversitesi, Eğitim Fakültesi, Eğitim Bilimleri Bölümü, Düzce/Türkiye Assist. Prof. Dr., Duzce University, Faculty of Education, Department of Educational Sciences, Düzce/Turkey e-mail: enderkazak81@hotmail.com ORCID ID: orcid.org/0000-0001-5761-6330
} 


\title{
Students' Views on Support and Training Courses Applied on Weekdays: A Phenomenological Study
}

\begin{abstract}
The study aims to present students' views on the weekday practices of Support and Training Courses (STC) started to be implemented in 2014-2015 academic year in Turkey and directly affecting the upper structure of education with approximately 10 million students, 500 thousand teachers and 10 thousand principals since the 20182019 academic year. The research was designed as a descriptive (phenomenology) design among the qualitative research methods. The participants included students who participated in weekday STC in a public secondary school in Düzce Province during the second semester of the 2018-2019 academic year. The data were collected through semi-structured interviews and the content analysis technique was used to analyze the data. Results show that the students preferred the STC courses to increase their success on exams and courses, to comprehend course subjects which were not totally understood, get more information, review the courses and subjects. It was evident that the STC courses increased the academic success and motivation of the students and contributed to their socialization along with helping them gain planned and programmed study skills. When the suggestions given by the students to improve the quality of the courses are evaluated; rearrangement of STC hours during the week, keeping the break time longer at the beginning of the course for students' nutrient and energy needs, including sports and arts activities besides basic courses like Turkish, Mathematics, Science, Social Studies are founded necessary. It is thought that the results will guide all stakeholders related to the courses, particularly the Ministry of National Education.
\end{abstract}

Keywords: Support and training course, student, secondary school, equality of opportunity, phenomenology.

\section{Giris}

Değişim ve dönüşümün çok hızlı yaşandığı dünyada, çağın gereklerine uygun olarak kendini yenileyebilen, sorgulayabilen, eleştirel düşünebilen ve hayata uyum sağlayabilen bireyler yetiştirmek ancak eğitimle mümkündür. Toplumların gelişmişliğini gösteren önemli göstergelerden biri, ait olduğu toplumda yaşayan bireylerin niteliği ve eğitime verilen önemle doğru orantılıdır (Canöz, 2014). En yaygın tanımıyla eğitim, bireyin davranışlarında kendi yaşantısı yoluyla kasıtlı olarak istendik yönde değişiklik meydana getirme sürecidir (Ertürk, 1997). Bu değişikliğin sağlanmasında, öğrenme ve öğretme süreçlerinin etkililiği ve yeterliliği önemli rol oynar. Öğrenme, sosyal, psikolojik, fiziksel ve çevresel birçok unsurdan etkilenen ve aynı zamanda bu unsurları etkileyen bir süreçtir (Yılmaz, 2009). Öğrenme, var olan toplumsal duruma, kurallara ve kültürel gereklere ayak uydurma biçimidir (Kaya, 2012). Öğrencilerin öğrenme düzeylerinde bireysel özellikler, ülkenin ekonomik şartları, teknolojik yapılar, politikalar, programlar, öğretmenler, aileler vb. unsurlar nedeniyle farklılıklar görülebilmektedir. Öğrenme üzerinde etkili olan bu unsurlar nedeniyle öğrenmenin istenen düzeyde olmaması, eksik öğrenmelerin tamamlanması için takviye edici eğitimler ihtiyaç haline gelmektedir. Davis ve Sorel (1995), öğrencilerin istenilen başarıya ulaşamadıkları durumlarda takviye eğitim alması gerektiğini ifade etmektedir. Türkiye'de ilköğretimden sonra bir üst eğitim kurumuna öğrenci yerleştirmenin yani Liselere Giriş Sınavi'nın (LGS) merkezi sınavla yapılıyor olması, öğrencilerin birbirleriyle bir yarış ortamına girmesi ve başarı düzeylerini artırma istekleri, ihtiyaç duyulan bu ek eğitimlere talepleri 
artırmaktadır. Bu nedenle, öğrenciler hem okul sınavlarında başarılı olmak hem de merkezi sinavlara daha iyi hazırlanmak amacıyla özel derslere, özel eğitim merkezlerine, dershanelere ve okullardaki hafta sonu kurslarına yönelmektedir (Uğurlu ve Aylar, 2017). Nitelikli liselerin kontenjanları sınırlı, talep fazla olduğunda, talep edenleri bir şekilde başarı durumlarına göre sıralamaktan başka çözüm görülmemektedir (Büyüköztürk, 2016). Nitelikli liselere olan talebin fazlalığ nedeniyle, uygulanan merkezi yerleştirme sınavlarına hazırlanma, öğrenci ve veliler için oldukça önemlidir. Bu durumdan dolayı öğrenciler ve veliler de merkezi sınavlara hazırlanmak için takviye kurs imkânı aramaktadır. Ancak; özel kurs merkezleri aracılığı ile yapılan bu takviye eğitiminin mali boyutu velileri zorlayabilmektedir.

Ailelerin ekonomik düzeylerinin düşük oluşu ve eğitime bakış açıları, çocuklarının takviye eğitim alma imkânını sınırlandırmaktadır. Bu durum eğitimde fırsat eşitliğini olumsuz yönde etkileyebilmektedir. Eğitim sisteminin tüm unsurlarının tüm bireylere başarıyı ve gelecek fırsatını yakalayacak şekilde sunulması gerekmektedir (Mercik, 2015). Eğitimde fırsat eşitliği, bireylere eşit ve kaliteli bir eğitim alma hakkı sunmaktır. Eğitim hakkı, bireyin en temel hakları arasındadır (Türküresin, 2018). Milli Eğitim Bakanlığı (MEB) fırsat eşitliği konusundaki yukarıdaki olumsuz durumu ortadan kaldırmak için, ortaokul ve liselerde öğrenimlerine devam eden öğrencilerle, liselerden mezun olmuş bireylere merkezi sınavlara hazırlanma konusunda fırsat ve imkân eşitliği sağlamak amacıyla 2014-2015 eğitim-öğretim yılı itibariyle örgün ve yaygın eğitimi destekleme ve yetiştirme kursları uygulamasını hayata geçirmiştir (Milli Eğitim Bakanlığı Örgün ve Yaygın Eğitimi Destekleme ve Yetiştirme Kursları Yönergesi [MEB], 2014: madde 1). MEB tarafından yayımlanan yönetmelik ile 2015-2016 eğitim-öğretim yılı itibariyle dershaneler kapatılmıştır (Milli Eğitim Bakanlığı Özel Öğretim Kurumları Yönetmeliğinde Değişiklik Yapılmasına Dair Yönetmelik [MEB], 2015: madde 1-23). 2014-2015 eğitim-öğretim yılı itibari ile uygulamaya konulan destekleme ve yetiştirme kursları resmi/özel örgün ve yaygın eğitim kurumlarında öğrenim gören öğrenci ve kursiyerlere yönelik ücretsiz bir şekilde verilmekte, bu da kursları daha cazip hale getirmekte ve istatistiksel olarak bu kurslara katılan öğrenci ve öğretmen sayısında her eğitim-öğretim yılı artış yaşanmasına neden olmaktadır (MEB, 2016a, 32).

Açlan destekleme ve yetiştirme kurslarının benzeri uygulamalar, dünyanın farklı ülkelerinde de bulunmaktadır. McKinsey Company (2007) tarafından, dünyada başarılı eğitim sistemleri üzerinde yapılan çalışmada, akademik anlamda yetersiz olan öğrenciler için destekleme ve yetiştirme amaçlı ilave ders ya da kurs gibi uygulamaların, bazı ülkelerde görüldüğü belirtilmektedir. Japonya'da, öğrencilerin derslerini takviye amaçlı, öğrencileri sınavlara hazırlayan ve veliler tarafından finanse edilen Jukular mevcuttur. Jukular, akşam saatlerinde ve hafta sonlarında faaliyet göstermektedirler (Kıral, 2009). Singapur'da \%20'lik alt gruptaki öğrenciler için okuldan sonra yetiştirme kurslarının yapılması, Yeni Zelanda'da öğrencilerin okumalarını desteklemek adına destekleyici kursların yapılması da örnek olarak gösterilmektedir. Yine, Güney Kore' de 2011 verilerine göre ek derslere katılım oranı ilkokul düzeyinde $\% 85$, ortaokul düzeyinde $\% 75$, lise düzeyinde ise $\% 58$ 
civarlarındadır. İngiltere ve Fransa gibi ülkelerde de ders saati dişındaki zamanlarda özellikle hafta sonlarında destek eğitimleri yapılmaktadır (Atabay, 2019).

Ülkemizde 2014 yılında faaliyete geçen DYK, gerek merkezi sınavlara olan etkisi, gerekse yetiştirilemeyen konuların tamamlanmasında oldukça etkili hale gelmiştir. Destekleme ve yetiştirme kurslarının günümüzde eğitim sürecinin bir parçası olduğu görülmektedir (Canbolat ve Köçer, 2017). Ders dişı etkinlikleri formal öğretim etkinliklerinden bağımsız düşünmek olanaklı değildir. Burada en önemli koşul, ders dışı etkinliklerin kontrollü, programlı ve planlı bir şekilde yapılmasıdır (Köse, 2013). DYK uygulamasının henüz yeni olması sebebiyle bazı eksiklikler ve sorunlar ortaya çıkabilmektedir. İlgili çalışmalar incelendiğinde, kurslar yorucu olduğu için öğrencilerin kurslara katılmak istemediği (Türküresin, 2018), öğrencilerin doküman eksikliği yaşadığı, kurslarda sıkıldıkları, kursların hafta içi olmasından rahatsızlık duydukları, aileyle vakit geçirememekten şikâyetçi oldukları ve sosyal olarak kısıtlandıkları görülmektedir (Yirci ve Açıkgöz, 2018). Destekleme ve yetiştirme kurslarının olumsuz olduğu kadar olumlu yönleri de bazı çalışmalarda tespit edilmiştir. Bozbayındır ve Kara (2017) yaptıkları çalışmada kursların, öğrencilerin okul derslerine destek olması, öğretmene maddi destek sağlaması, öğretmenlerin mesleki gelişimini sağlaması ve maddi durumu iyi olmayan öğrencilere destek olması gibi olumlu katkılarının olduğunu tespit etmişlerdir. Ayrıca Ünsal ve Korkmaz (2016) çalışmalarında kursların, öğrencilerin ders ve sınav başarılarını arttırıp soru çözme becerilerini geliştirerek katkı sağladığını tespit etmişlerdir. Bu kurslarda aksayan yönlerin ve yaşanan sorunların ortaya çıkarılmasının ve analiz edilmesinin, bu kursların verimliliğini ve kalitesini artıracağı düşünülmektedir. Bu bağlamda, örgün ve yaygın eğitimi destekleme ve yetiştirme kurslarına devam eden ve uygulamanın merkezinde olan öğrenci ve kursiyerlerden bu kurslara ilişkin görüşlerin alınması, kurslarda yaşanan sorunların ve aksayan yönlerin tespit edilmesi önemlidir. Destekleme ve yetiştirme kurslarının hafta içi uygulanmasına ilişkin alanyazında henüz çalışma yapılmadığı, yapılan bu çalışmanın bu anlamda hem uygulayıcılara hem politika yapıcılara hem de alanyazına katkı sağlayabileceği düşünülmektedir. Destekleme ve yetiştirme kurslarının hafta içi uygulanmasının, öğrencilerin gözüyle ele alınarak incelenmesinin, uygulayıcılara kursların verimliliğini artıracak önlemlerin alınması noktasında katkı sağlayabileceği düşünülmektedir.

\section{Araştırmanın Amacı}

2014-2015 eğitim-öğretim yılında uygulamaya giren, dershaneler ile özel eğitim kurslarının yerini aldığı düşünülen destekleme ve yetiştirme kurslarının işleyişi ve verimliliği son derece önemlidir. Her öğrenci, özel eğitim kurumu, etüt merkezi veya dershane gibi ücretli olan takviye eğitim merkezlerine gitme imkânına sahip değildir. $\mathrm{Bu}$ açıdan bakıldığında okullarda ücretsiz açılan kurslar ayrı bir önem kazanmaktadır (Uğurlu ve Aylar, 2017). Öğrencilere akademik, psikolojik, ekonomik ve sosyolojik açıdan olumlu katkılarının olduğu (Nartgün ve Dilekçi, 2016) bilinen destekleme ve yetiştirme kurslarıyla ilgili alanyazında yeterli sayıda çalışmanın olmadığ1 söylenebilir. Bu nedenle öğrenciler tarafından yoğun talep gören, sonuçlarıyla öğrenci, veli ve öğretmenleri etkileyen, eğitim sistemi için oldukça yeni olan bu uygulamanın araştırılması önem arz etmektedir. Bu kurslarda aksayan 
yönlerin ve yaşanan sorunların ortaya çıkarılmasının bu kursların verimliliğini ve kalitesini artıracağ1 düşünülmektedir. Bu kapsamda, DYK'ya katılan ortaokul öğrencilerinin DYK'nın hafta içi uygulanmasına yönelik görüşlerinin neler olduğunun araştırılması amaçlanmıştır.

$\mathrm{Bu}$ bağlamda araştırmanın amacı, MEB'e bağlı ortaokullarda yürütülen ve ülkemizde milyonlarca öğrenciyi ilgilendiren destekleme ve yetiştirme kurslarının hafta içi uygulanması sürecinin nasıl işlediğini ve bu süreçte hangi sorunların yaşandığını öğrencilerin görüşleri doğrultusunda tespit etmektir. Bu doğrultuda, aşağıdaki sorulara yanıt aranmıştır:

1. Öğrencilerin hafta içi destekleme ve yetiştirme kurslarını tercih etme nedenleri nelerdir?

2. Hafta içi destekleme ve yetiştirme kurslarında görev alan öğretmenlerin etkililiği ile ilgili öğrenci görüşleri nelerdir?

3. Hafta içi destekleme ve yetiştirme kurslarının öğrencilere sağladığı katkılar nelerdir?

4. Hafta içi destekleme ve yetiştirme kurslarının olumsuz/aksayan yönleri nelerdir?

5. Hafta içi destekleme ve yetiştirme kurslarının verimliliğini artırmaya yönelik öğrenci önerileri nelerdir?

\section{Yöntem}

$\mathrm{Bu}$ bölümde araştırmanın modeli, araştırmanın çalışma grubu, veri toplama aracı ve veri toplama aracının geliştirilmesi süreci ile verilerin analizine ilişkin bilgiler yer almaktadır.

\section{Araştırma Deseni}

Hafta içi destekleme ve yetiştirme kurslarına katılan ortaokul öğrencilerinin destekleme ve yetiştirme kurslarına ilişkin görüşlerini tespit etmek amacıyla gerçekleştirilen bu çalışma nitel araştırma yönteminde tasarlanmıştır. Nitel araştırmaların gözle görülür özelliklerinden birisi, doğal ortamında oluşan olgu ya da davranışlar üzerine odaklanmasıdır (Büyüköztürk, Kılıç Çakmak, Akgün, Karadeniz ve Demirel, 2016). Çalışmada, nitel araştırma yöntemlerinden biri olan betimsel fenomenoloji deseni kullanılmıştır. Fenomenoloji (Olgubilim) deseni, bireylerin bakış açısından algı ve deneyimlerini ön plana çıkarmayı hedefleyen nitel bir araştırma desenidir (Ersoy, 2017). Farkında olup da derinlemesine ve ayrıntılarıyla bilgi sahibi olmadığımız olgulara odaklanan fenomenoloji deseni, bireylerin bir olguya ilişkin görüşlerini, düşüncelerini, yaşantılarını ve bunlara yükledikleri anlamları ortaya çıkarmada oldukça etkilidir (Yıldırım ve Şimşek, 2018).

\section{Çalışma Grubu}

Araştırmanın katılımcılarını, 2018-2019 eğitim-öğretim yılında Düzce il merkezinde bulunan bir kamu ortaokulunun 5., 6., 7. ve 8. sınıflarında öğrenim gören, destekleme ve yetiştirme kurslarına katılan 35 öğrenci oluşturmaktadır. Öğrencilerin yaş ortalamasının düşüklüğü ve kendilerini ifade etmede yaşanabilecek zorluklar nedeniyle katılımcı sayısı yüksek tutulmuştur. Çalışma grubu, amaçlı örnekleme yöntemlerinden ölçüt örneklem ve maksimum çeşitlilik örneklem yöntemiyle 
belirlenmiştir. Ölçüt örnekleme yöntemindeki temel anlayış, araştırmacı tarafından daha önceden belirlenmiş bir dizi ölçütü karşılayan tüm durumların çalışılmasıdır. Maksimum çeşitlilik örneklem yöntemindeki temel anlayış ise göreli olarak küçük bir örneklem oluşturmak ve bu örneklemde çalışılan probleme taraf olabilecek bireylerin çeşitliliğini maksimum derecede yansıtmaktır (Yıldırım ve Şimşek, 2018). Araştırmada, destekleme ve yetiştirme kurslarının hafta içi uygulamalarına katılmış olmak ve ortaokul öğrencisi olmak ölçütleri esas alınmış ve her sınıf düzeyinden öğrencinin katılımıyla maksimum çeşitlilik sağlanmaya çalışılmıştır. Bu ölçütleri karşılayan 46'sı erkek ve 48'i kız olmak üzere toplamda 94 öğrenciden 15'i erkek ve 20'si kız olmak üzere toplam 35 öğrenci görüşmeyi kabul etmiştir. Katılımcıların betimleyici özellikleri Tablo 1'de gösterilmiştir.

Tablo 1.

Öğrencilerin Betimleyici Özellikleri

\begin{tabular}{lccc}
\hline \multicolumn{1}{c}{ Grup } & Katılımcilar & $f$ & \% \\
\hline \multirow{3}{*}{ Cinsiyet } & Erkek & 15 & 42,9 \\
& Kadın & 20 & 57,1 \\
\hline \multirow{3}{*}{ Sinıf Düzeyi } & 5 & 9 & 25,7 \\
& 6 & 11 & 31,4 \\
& 7 & 9 & 25,7 \\
& 8 & 6 & 17,1 \\
\cline { 2 - 4 } & Toplam & $\mathbf{3 5}$ & $\mathbf{1 0 0}$ \\
\hline
\end{tabular}

Araştırmaya katılan öğrencilerin cinsiyet dağılımları birbirine yakın olup kız öğrencilerin oranı daha fazladır. Ayrıca her sınıf düzeyinden katılımcıların sayıları 6 ile 11 arasında değişmektedir (Tablo1).

\section{Veri Toplama Araci}

Öğrencilerin hafta içi destekleme ve yetiştirme kursları ile ilgili görüşlerini belirlemek amacıyla araştırmacı tarafından geliştirilen yarı yapılandırılmış görüşme formu kullanılmıştır. Yarı yapılandırılmış görüşmeler, sabit seçenekli cevaplamanın yanında belli bir alanda derinlemesine inceleme yapılmasını da sağlamaktadır (Büyüköztürk vd., 2016). Görüşme formunu hazırlama sürecinde geçerlik ve güvenirlik çalışması kapsamında; alanyazın taranmış, eğitimi destekleme ve yetiştirme kursu yönergesi incelenmiş, elde edilen bilgiler ışığında açık uçlu sorular hazırlanmıştır. İç geçerlilik için, hazırlanan sorularla ilgili olarak alan uzmanı iki akademisyenin görüşü ve katılımcı teyidi alınmış, bu görüşler doğrultusunda gerekli düzeltmeler yapılmıştır. Başlangıçta 9 soru olarak hazırlanan görüşme formu, iki uzmanın ortak görüşü doğrultusunda 5 soru olarak düzenlenerek revize edilmiştir. Kapsam geçerliliği için uzman görüşü alınan form, bir dil uzmanının görüşü doğrultusunda düzenlenerek beş öğrenciye (araştırma grubu dişında) ön uygulama yapılmıştır. Ön uygulamada, soruların katılımcılar tarafından doğru anlaşıldığı belirlenmiş ve görüşme formuna son şekli verilmiştir.

\section{Verilerin Toplanması}

Araştırmanın verileri, 15 gün süren çalışma sonucunda toplanmıştır. Görüşme formunda yer alan sorular, 2018-2019 Eğitim-Öğretim yılının 2. döneminde açılan 
destekleme ve yetiştirme kurslarına katılmış öğrencilerden, görüşmeyi kabul eden 35 öğrenciye sözel olarak yöneltilmiştir. Görüşmeler, görüşmecilere uygun gün ve saatlerde yüz yüze yapılmıştır. Görüşmeye katılan her öğrenciden izin verdiklerine dair imzalı belge alınmış ve sorulara verdikleri yanıtlar yine kendi izinleri doğrultusunda ses kayıt cihazı ile kaydedilmiştir. Görüşmeler ortalama 25 dakika sürmüştür. Her bir öğrenciye kod verilmiş, kodların verilmesinde öğrencinin sınıf seviyesi, cinsiyeti ve görüşme numarası göz önünde bulundurulmuştur. Kodlamanın, katılımcıları tam olarak gösterebilmesi açısından cinsiyet $\mathrm{E}$ ve $\mathrm{K}$ harfi, sınıf seviyesi 5, 6, 7, 8 sıra numaraları ise 1 ile 6 arasında planlanmıştır. Erkek öğrenciler, EÖ5-6-7-8, 1 ile EÖ5-6-7-8, 6 arasında, k1z öğrenciler KÖ5-6-7-8, 1 ile KÖ56-7-8, 6 arası numaralarla kodlanmıştır.

\section{Verilerin Çözümlenmesi ve Yorumlanması}

Öğrencilerin destekleme ve yetiştirme kursları ile ilgili görüşlerinin çözümlenmesinde nitel analiz yöntemlerinden içerik analizi tekniği kullanılmıştır. İçerik analizi yoluyla veriler tanımlanmaya, verilerin içinde saklı olabilecek gerçekler ortaya çıkarılmaya çalışılır. Temelde yapılan işlem, birbirine benzeyen verileri belirli kavramlar ve temalar çerçevesinde bir araya getirmek ve bunları okuyucunun anlayabileceği şekilde düzenleyerek yorumlamaktır. Nitel araştırma verileri dört aşamada analiz edilmektedir. İlk aşama verilerin kodlanması, ikinci aşama temaların bulunması, üçüncü aşama kodların ve temaların düzenlenmesi ve dördüncü aşama bulguların tanımlanması ve yorumlanması aşamasıdır (Yıldırım ve Şimşek, 2018). Kodlama aşamasında, araştırmacı tarafından veriler dikkatli bir şekilde okunmuş ve araştırmanın soruları kapsamında, önemli görülen kavramlardan hareketle kodlar oluşturulmuştur. Katılımcılardan toplanan verilerden önemli görülen doğrudan alıntılara yer verilerek kodlar teyit edilmiştir. Bulgular sunulurken bir düşüncenin kaç kez tekrar ettiği frekanslarla ilgili tema altında belirtilmiştir. Bazı öğrenciler birden fazla görüş belirttiği için bulgular kısmında toplam katılımcı sayısı olan 35'in üzerinde görüş oluşmuş bu görüşler de ayrıca kodlanarak belirtilmiştir. Çarpıcı görüşler aynen alınmış ve görüş sahibi öğrenciler kodlanmıştır. Her bir öğrencinin vermiş olduğu cevaplar ilgili tema içinde sistematik ve açık bir şekilde betimlenmiş ve verilen cevaplar, sorulardan yola çıkılarak oluşturulan temalar altında toplanmıştır.

\section{İnandirıcılık}

Bir araştırmanın önemi bilimsel alanyazına kattı̆̆ı bilgi ve insan yaşamında karşılaşılan sorunlara getirdiği çözüm çerçevesinde değerlendirilir. Bu iki amaca hizmet etme yanında, araştırmanın bilimsel olarak kabul edilmesi için araştırma sürecinin ve sonuçlarının açık, tutarlı ve başka araştırmacılar tarafından teyit edilebilir olması gerekir. Aksi takdirde araştırmanın inandırıcılığı konusunda kuşkular ortaya çıkabilir (Yıldırım ve Şimşek, 2018 277). İnandırıcılık, verilerin gerçeklikle bağdaşıp bağdaşmadığını göstermesi açısından oldukça önemlidir. Bu amaçla araştırmanın iç geçerliğini arttırmak amacıyla ilgili alanyazın taranmış ve araştırmaya ilişkin kavramsal çerçeve çizilerek görüşme formu hazırlanmıştır. Ayrıca katılımcıların düşüncelerini rahat yansıtmalarını sağlamak amacıyla, çalışmadan elde edilen bilgilerin akademik amaçla kullanılacağı ve isimlerinin gizli tutulacağı güvencesi verilmiştir. Araştırmacı tarafından tespit edilen kodlamaların 
doğruluğunu kontrol etmek amacıyla nitel çalışmalar yapmış olan iki öğretim üyesinin görüşleri alınmıştır. Bu görüşler sonrası, oluşturulan kodlamalar üzerinde düzenlemeler yapılmıştır. Böylece, araştırmanın iç güvenirliği (tutarlığını) arttırılmaya çalışılmıştır. Yapılan görüşmeler ses kayıt cihazına kaydedilmiş ve görüşme sonrası bilgisayar ortamına aktarılmıştır. Daha sonra bu ifadeler katılımcılar ile paylaşılarak, katılımcıların onayına sunulmuştur. Böylece araştırmanın yapı geçerliliği sağlanmaya çalışılmıştır.

\section{Bulgular}

Bu bölümde araştırmanın alt sorularına dayalı olarak oluşturulan temalar ve her temaya ilişkin kodlar öğrenci görüşlerine yer verilerek sunulmuştur.

\section{Hafta İçi Destekleme ve Yetiştirme Kurslarının Tercih Edilme Nedenlerine İlişkin Bulgular}

Hafta içi destekleme ve yetiştirme kurslarının öğrenciler tarafından tercih edilme nedenlerini belirlemeye yönelik olarak araştırmaya katılan öğrencilere, "Hafta içi destekleme ve yetiştirme kurslarm tercih etme nedenleriniz nelerdir?" sorusu yöneltilmiştir. Destekleme ve yetiştirme kurslarının öğrenciler tarafından tercih edilme nedenleri temasında; kursların “ders ve sınav başarısını artırmak (\%28,8), derslerde anlaşılmayan konuları daha iyi anlayabilmek $(\% 24,9)$, kurslarda daha çok bilgi öğrenmek $(\% 19,2)$, kurslarda ders ve konu tekrarı yapak (\%11,5), kursların eğlenceli geçmesi $(\% 5,8)$ " kodlarının ağırlıkta olduğu görülmektedir. “Hocaların çok iyi anlatması, kursların derslere motive etmesi, aile isteği, kurslarda kendini geliştirmek ve boş gezmeyi engellemek" kodlarının da \%1,9 oranında dile getirildiği görülmektedir.

Katılımcılar, hafta içi destekleme ve yetiştirme kurslarını tercih etme nedenleri ile ilgili birden fazla görüş belirttiği için frekans sayısı, katılımcı sayısından fazla çıkmıştır.

Tablo 2.

Hafta İçi Destekleme ve Yetiştirme Kurslarının Tercih Edilme Nedenlerine İlişkin Öğrenci Görüşleri

\begin{tabular}{clcc}
\hline Tema & Kodlar & $f$ & $\mathbf{\%}$ \\
\hline & Ders ve sinav başarısını artırmak & 15 & 28,8 \\
& Derslerde anlaşılmayan konuları daha iyi anlayabilmek & 10 & 24,9 \\
& Daha çok bilgi öğrenmek & 10 & 19,2 \\
& Ders ve konu tekrarı yapmak & 6 & 11,5 \\
& Kursların eğlenceli geçmesi & 3 & 5,8 \\
& Öğretmenlerin çok iyi anlatması & 1 & 1,9 \\
& Derslere motive etmesi & 1 & 1,9 \\
& Ailenin isteği & 1 & 1,9 \\
& Kendini geliştirmek & 1 & 1,9 \\
& Boş gezmeyi engellemek & 1 & 1,9 \\
\hline
\end{tabular}

Ders ve sınav başarısını artırmakla ilgili olarak öğrencilerin büyük bölümünün kursların sınav ve ders başarılarını artırdı ̆̆ görülmüştür. Bununla ilgili olarak: "Kursların sayesinde derslerimdeki başarım arttı. 
Okulda ve evde kendimi daha iyi hissetmeye başladım. Notlarım yükseldi. KÖ6-1", "Sinavlarda puanım arttı. Geçen sene belge alamama rağmen bu sene kurslarn sayesinde başarılarım arttı. Hatta belge aldım EÖ8-2", "Illkokuldaki başarımın üzerine çıkmayı kursların sayesinde başardım. EÖ5-2" şeklinde görüşler dile getirilmiştir.

Konuları daha iyi anlamakla ilgili olarak öğrenciler: "Konuları kurslarla beraber işlediğimizde sorular çözüldüğü için daha iyi anlayabiliyorum. EÖ7-3", "Kursların konuları daha iyi anlamamı sağladığını düşünüyorum. KÖ6-4" şeklinde görüşler dile getirmişlerdir.

Kurslarda daha fazla bilgi öğrenmekle ilgili olarak, "Hem ailem katılmamı istiyor hem kendim katılmak istiyorum. Çünkü ders ve sinavlarda oldukça yüksek notlar alıyorum. Ayrica daha çok bilgi öğrenmek için istiyorum. EÖ6-2", "Kurslarda yeni yeni ve çok bilgiler öğreniyorum. EÖ6-3" şeklinde görüşler dile getirilmiştir.

Kurslarda tekrar yapmakla ilgili olarak ise "Derste öğrenemediğim konular kursta tekrar ettiğimiz için öğrenebiliyorum. KÖ7-1", "Kurslarda bol bol tekrar yapryoruz. EÖ6-1" şeklinde görüşler dile getirilmiştir.

Kursların eğlenceli geçmesi ile ilgili olarak "Hafta içi kurslarda bol bol etkinlik yapıyoruz. Eğitici ve eğlendirici oyunlar oynuyoruz. KÖ6-3", "Derslerde akill tahta üzerinden öğretmenlerin yarışma yapacă̆ı zamanlarda çok mutlu oluyorum. Bu nedenle kurslara kalmaktan dolayı mutlu oluyorum. EÖ7-4" şeklinde görüşlerini ifade etmişlerdir.

Öğretmenlerin çok iyi anlatmasıyla ilgili, "Öğretmenler kurslarda önceki konuları anlayabilmem için tekrarlar yapıyorlar bu da benim kurslara kalmamı sağlıyor. KÖ6-5" şeklinde görüşünü ifade etmiştir.

Derslere motive etmesi hususunda, "Kurslarda başarıl oldukça derslere olan ilgim yükseldi. Derslerde konuları daha iyi anlamaya başladım. EÖ8-4" şeklinde görüşünü ifade etmiştir.

Ailenin isteği ile ilgili olarak "Kurslarda ailemin isteği ile kalmaktayım. Ailem kurslara kalırsam ders ve sınav başarımın artacağını düşünüyor. EÖ8-3" şeklinde görüşünü dile getirmiştir.

Kendini geliştirmek konusunda "Kurslarda öğrenilen bilgilerin ileriki sınıflar için temel olacağı ve üst sınıflarda beni başarıya ulaştırmada yardımcı olacağını düşündüğüm için kurslarn tercih ettim. KÖ5-2" şeklinde görüşünü dile getirmiştir.

Boş gezmeyi engellemek ile ilgili "Okul sonrası genellikle bisikletimle alışveriş merkezi ve oyun sahalarna doğru gidiyorum. Bu durumu engelleyebilmek için kurslarda ders işlemeyi tercih ettim. EÖ8-6" şeklinde görüşünü ifade etmiştir.

Kursların tercih edilmesinde ana etkenin sınav ve ders başarısını artırmak olduğu, bununla beraber konuların tekrar edilme ihtiyacının ve anlaşılamayan konuların da öğrenilme çabasının kurslara olan talep üzerinde doğrudan etkisi olduğu ortaya çıkmıştır.

\section{Hafta İçi Destekleme ve Yetiştirme Kurslarında Görev Alan Öğretmenlerin Etkililiğine İlişkin Bulgular}

Hafta içi destekleme ve yetiştirme kurslarında görev alan öğretmenlerin etkililiği temasını belirlemek amacıyla katılımcılara, "Hafta içi destekleme ve yetiştirme kurslarnda görev alan öğretmenlerin etkililiği/motivasyonlarl/gayretleri ile ilgili görüşleriniz nelerdir?" sorusu yöneltilmiştir. Öğretmenlerin etkililiği teması altında, "öğretmenler çok verimli $(\% 70,5)$, öğretmenler çok eğlenceli ders işliyorlar $(\% 18,2)$, öğretmenlerin 
motivasyonu çok iyi $(\% 4,5)$, motivasyonları çok iyi ama biraz daha iyi olabilir $(\% 4,5)$ ve bazı öğretmenlerin motivasyonu çok iyi bazıları ise isteksiz (\%2,3)" kodlarına ulaşılmıştır.

Tablo 3.

Hafta İçi Destekleme ve Yetiştirme Kurslarında Görev Alan Öğretmenlerin Etkililiği ile İlgili Görüşleri

\begin{tabular}{|c|c|c|c|}
\hline Tema & Kodlar & f & $\%$ \\
\hline \multirow{5}{*}{ 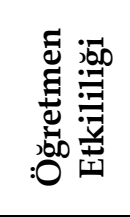 } & Öğretmenler çok verimli & 31 & 70,5 \\
\hline & Öğretmenler çok eğlenceli ders işliyor & 8 & 18,2 \\
\hline & Öğretmenlerin motivasyonu çok iyi & 2 & 4,5 \\
\hline & Motivasyonları çok iyi ama biraz daha iyi olabilir & 2 & 4,5 \\
\hline & Bazı öğretmenlerin motivasyonu çok iyi bazıları ise isteksiz & 1 & 2,3 \\
\hline Toplam & & 44 & 100 \\
\hline
\end{tabular}

Katılımcıların, hafta içi destekleme ve yetiştirme kurslarında görev alan öğretmenlerin etkililiği ile ilgili birden fazla görüş belirtmesi nedeniyle frekans sayısı, katılımcı sayısından fazla çıkmıştır.

Öğretmenlerin kursları verimli işlediğine ilişkin: "Kurslarda öğretmenlerimiz dersleri çok verimli, iyi işliyor. Konularn ve dersleri tekrar ediyorlar. Sorularn tek tek nedenleriyle açıklayarak çözüyorlar. KÖ6-4", "Kurslarda derslerimiz çok verimli geçiyor. Oldukça başarılı bir öğrenci olmamda kursların katkısı oldukça fazladır. Ayrıca kurslar hafta içi 7. dersten sonra yapıldı ğ için dersle ilgili eğlenceli oyunlar da oynayabiliyoruz. EÖ5-2" şeklinde görüşler dile getirilmiştir.

Öğretmenlerin kursların eğlenceli işlemesine ilişkin ise genel olarak öğrencilerin KÖ6-3'ün görüşünde olduğu gibi “Çok iyi ve eğlenceli ders anlatryorlar. Zaman zaman kurslarda eğlenceli etkinlikler yapıyoruz. Sınavlara çalıştırıyorlar. Çok memnunum." tespit edilmiştir.

Öğretmenlerin motivasyonunun çok iyi olması ile ilgili “Öğretmenlerimiz çok motivasyonlu oluyor. Genelde yarışmalar yapıyoruz ve bilgiler daha çok aklımızda kalıyor. (KÖ7-1) şeklinde görüşler belirtilmiştir.

Motivasyonları çok iyi ama biraz daha iyi olabilir ile ilgili olarak "Öğretmenlerin motivasyonu çok iyi ama bazı zamanlarda sadece test kâğı dı veriyorlar. Test süresi bitince de cevapların söylüyorlar. Cevaplarn açılamadan kursu bitiriyorlar. KÖ5-3" şeklinde görüş belirtilmiştir.

Bazı öğretmenlerin motivasyonu çok iyi bazıları ise isteksiz ile ilgili olarak "Bazı öğretmenler kurslarda aynı derslerde oldŭ̆u gibi hareketli ve istekli biçimde ders işlerken bazı öğretmenlerse sadece test kâğıdını veriyor. Bizlerle fazla ilgilenmiyor. EÖ5-3" şeklinde görüş ifade edilmiştir.

Öğretmen motivasyonunun ele alındığı bu temada, öğrencilerin cevaplarının büyük oranda birbirine benzediği, öğretmen motivasyonlarının çok yüksek olduğu, kursların çok verimli geçtiği ancak düşük oranda da olsa öğretmenlerin yedinci dersten sonra kurslarda verimli olamadıkları sonuçları ortaya çıkmıştır. 


\section{Hafta İçi Destekleme ve Yetiştirme Kurslarının Sağladı̆̆ı Katkılara İlişkin Bulgular}

Hafta içi destekleme ve yetiştirme kurslarının ortaokulda öğrenim gören öğrencilere olan katkısını belirlemek amacıyla araştırmaya katılan öğrencilere, "Hafta içi destekleme ve yetiştirme kurslarını size sağladığı katkılar nelerdir?" sorusu yöneltilmiştir. Kursların sağladığı katkı teması altında, "sınavlardan daha iyi notlar alma $(\% 63,2)$, anlamadığı konuları daha iyi anlama $(\% 23,6)$, oyun ve testler sayesinde çok öğrenme $(\% 5,3)$, derslere daha çok katılma $(\% 5,3)$, derslere çalışmış olma $(\% 2,6)$ " kodlarına ulaşılmıştır.

Tablo 4.

Hafta İçi Destekleme ve Yetiştirme Kurslarının Öğrencilere Sağladı̆̆ı Katkılar

\begin{tabular}{|c|c|c|c|}
\hline Tema & Kodlar & $f$ & $\%$ \\
\hline \multirow{5}{*}{ 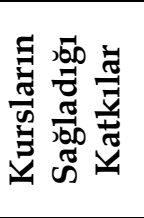 } & Sinavlardan daha iyi notlar alma & 24 & 63,2 \\
\hline & Anlamadığı konuları daha iyi anlama & 6 & 23,6 \\
\hline & Oyun ve testler sayesinde çok öğrenme & 2 & 5,3 \\
\hline & Derslere daha çok katılma & 2 & 5,3 \\
\hline & Derslere çalışmış olma & 1 & 2,6 \\
\hline Toplam & & 38 & 100 \\
\hline
\end{tabular}

Katılımcıların, hafta içi destekleme ve yetiştirme kurslarının sağladığı katkılara ilişkin birden fazla görüş belirtmesi nedeniyle frekans sayısı, katılımcı sayısından fazla çıkmıştır.

Öğrencilerin DYK'nın öğrencilere sağladığı katkılara ilişkin sınavlardan iyi not alma ile ilgili: "Sınavlarda eskiden sorular düşünürken soruyu iki dakikada zor yapıyorsam şimdi bir dakikada yapıyorum. Bu sayede notlarm yükseliyor. EÖ8-1", "Lise hazırlk sinavlarında ve ders sinavlarında notlarm yükseldi. KÖ8-4", "Sinav sonuçlarm eskiye göre oldukça başarılı durumda. EÖ7-3" şeklinde görüşler dile getirilmiştir.

DYK'nın öğrencilere sağladığı katkılardan, konuları daha iyi anlama ile ilgili: "Derslerde anlatılan konuları kursta tekrar anlattıkları için çok daha iyi anlıyorum. KÖ7- 5", "Kurslarda işlediğimiz konularla ilgili bol bol test çözdüğümüz için konulan daha iyi anlıyorum. EÖ5-2" şeklinde görüşler dile getirilmiştir.

Oyun ve testler sayesinde öğrenme ile ilgili "Kurslarda eğitici ve eğlendirici oyunlar sayesinde konular hem daha çok aklımda kalıyor. Hem de öğrendiğim bu bilgiler derslerde de bana yardımcı oluyor. EÖ8-4" şeklinde görüş belirtmiştir.

Derslere daha çok katılma ile ilgili "Derslere katılımım arttı. İlkokulda derslere olan katılımım oldukça düşüktü. Kurslar sayesinde konuları tekrar anlattıkları için ders notlarım ile ders içi katılımım arttı. (KÖ6-5)" şeklinde görüş ifade edilmiştir.

Derslere çalışmış olmak ile ilgili "Derslere evde çalışmak yerine hafta içi kurslarında farkl derslerden en azından iki sat çalışmış oluyorum. Eve gidince de dinlenme ve eğlenmeye böylece vaktim kahyor. (KÖ8-4)" şeklinde görüş belirtmiştir.

Hafta içi kurslarının öğrencilere sağladığı katkılar değerlendirildiğinde daha çok sınavlardan iyi not alma ve anlamadıkları konuları daha iyi anlamak şeklinde bulguların ortaya çıktığını söyleyebiliriz. 


\section{Hafta İçi Destekleme ve Yetiştirme Kurslarının Aksayan/Olumsuz Yönleri İle İlgili Bulgular}

Hafta içi destekleme ve yetiştirme kurslarının ortaokul öğrencilerine göre aksayan/olumsuz yönlerini belirlemek amaciyla öğrencilere, "Hafta içi destekleme ve yetiştirme kurslarının memnun olmadığınız (olumsuz/eksik/aksayan olan) yönleri var mıdır? Varsa nelerdir?" sorusu yöneltilmiştir. Kurslarının olumsuz/aksayan yönleri teması altında, "olumsuz/aksayan yön yok $(\% 66,7)$, derslerden sonra yorgun düşmek, anlamakta zorlanmak $(\% 16,6)$, eğlenceli yarışmaların eksik olması $(\% 13,9)$, öğretmenler yorgun olduğu için çok fazla etkinlik yapamamak (\%2,8) kodlarına ulaşılmıştır.

Tablo 5.

Hafta İçi Destekleme ve Yetiştirme Kurslarının Aksayan/Olumsuz yönleri

\begin{tabular}{|c|c|c|c|}
\hline Tema & Kodlar & $\mathbf{f}$ & $\%$ \\
\hline \multirow{4}{*}{ 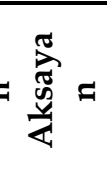 } & Aksayan/olumsuz yön yok & 24 & 66,7 \\
\hline & Derslerden sonra yorgun düşmek, anlamakta zorlanmak & 6 & 16,6 \\
\hline & Eğlenceli yarışmaların eksik olması & 5 & 13,9 \\
\hline & Öğretmenler yorgun olduğu için çok fazla etkinlik yapamamak & 1 & 2,8 \\
\hline \multicolumn{2}{|l|}{ Toplam } & 36 & 100 \\
\hline
\end{tabular}

Katılımcıların, hafta içi destekleme ve yetiştirme kurslarının aksayan/olumsuz yönlerine ilişkin birden fazla görüş belirtmesi nedeniyle frekans sayısı, katılımcı sayısından fazladir.

Hafta içi DYK'da öğrencilerin memnun olmadığı hususlara ilişkin: "Kurslardan çok memnunum çok eğlenceli geçiyor. EÖ5-4", "Kurslardan çok memnunum bol bol yarışma yapıp eğleniyoruz. KÖ6-5", "Genel olarak memnunum ama bazen yorgun olduğum için kalmak istemediğim zamanlar oluyor. KÖ8-2" şeklinde görüşler dile getirilmiştir.

Yedinci dersten sonra yorgun düşmek, anlamakta zorlanmak ile ilgili "7.Dersten sonra yorgun düşüyoruz. Bazı günler Türkçe, matematik ve fen dersleri üzerine kurs geliyor bu durumda da kurslar çekilmez olabiliyor. (EÖ6-4)" şeklinde görüşünü ifade etmiştir.

Eğlenceli yarışmaların eksik olması ile ilgili "Çoğunlukla test çözüyoruz ama ben daha çok oyunlarla işlemek istiyorum. Oyunlarla kursta daha çok eğleniyor ve daha çok öğreniyorum. Bence, bütün kurslarda hep eğlenceli yarışmalar yapılmalı. EÖ6-2" şeklinde görüşünü dile getirmiştir.

Öğretmenler yorgun olduğu için çok fazla etkinlik yapamamak ile ilgili "Öğretmenler yorgun düştükleri için etkinlik yerine test çözüyorlar. Öyle olunca da kurslar sıkıcı geliyor. Kalmak istemiyorum. EÖ7-5" şeklinde görüş belirtmiştir.

Hafta içi destekleme kurslarının aksayan yönlerinin değerlendirildiği bu temada, öğrencilerin büyük oranda kurslarda aksayan bir yönün bulunmadiğ yönünde görüş bildirdikleri görülmüştür. Bununla birlikte, öğrencilerin yorgun düşmeleri nedeniyle anlamakta zorlandıkları; öğretmenlerin yorgun düşmeleri nedeniyle de fazla etkinlik yapamadıkları gibi aksamaların yaşandığı dile getirilmiştir. 


\section{Hafta İçi Destekleme ve Yetiştirme Kurslarının Verimliliğini Artırmak İçin Öğrencilerin Önerilerine İlişkin Bulgular}

Hafta içi destekleme ve yetiştirme kurslarının verimliliğini artırmak için ortaokul öğrencilerinin önerilerini öğrenmek amaciyla öğrencilere, "Hafta içi destekleme ve yetiştirme kursları daha verimli hale nasıl getirilebilir? Sizce neler yapılabilir?" sorusu yöneltilmiştir. Ortaokul öğrencilerinin hafta içi destekleme ve yetiştirme kurslarının verimliliğini artırmaya yönelik önerileri teması altında, "Fikrim yok (\%22,9)", "oldukça verimli, aynı şekilde devam etmeli $(\% 20,0)$ ", "Hafta içi kurs başlamadan önceki teneffüs yarım saat veya bir saat olmalı $(\% 17,2)$ ”, “Kurslarda testlerin yanında eğlenceli oyunlar da olmalı $(\% 11,5)$ ", "Kurslar başlamadan dinlendirici etkinlikler yapılmalı $(\% 8,6)$ ", "Destekleme ve yetiştirme kurslarının hepsi hafta içi olmalı $(\% 5,7)$ ", "Kurslarda daha farklı ve fazla materyal kullanılmalı $(\% 5,7)$ ", "Hafta içi kursları başlamadan yemek verilmeli $(\% 2,8)$ ", "Sadece belirli sayıda kurs değil, talep edilen sayıda kurs olmalı (\%2,8)", "Hafta içi kursları test ve oyun çözmek yerine etkinlik üzerine kurulmalı" ve "sosyal, sportif vb. etkinlik üzerine kurulmalı $(\% 2,8)$ " kodlarına ulaşılmıştır.

Tablo 6.

Hafta İçi Destekleme ve Yetiştirme Kurslarmm Verimliliğini Artırmaya Yönelik Öğrencilerin Önerileri

\begin{tabular}{|c|c|c|c|}
\hline Tema & Kodlar & $\mathbf{f}$ & $\%$ \\
\hline \multirow{10}{*}{ 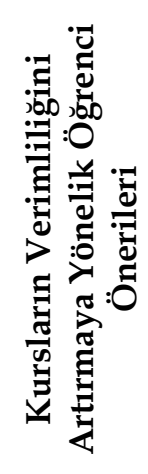 } & Fikrim yok & 8 & 22,9 \\
\hline & Oldukça verimli, aynı şekilde devam etmeli & 7 & 20,0 \\
\hline & Kurs başlamadan önceki teneffüs yarım saat veya bir saat olmalı & 6 & 17,2 \\
\hline & Kurslarda testlerin yanında eğlenceli oyunlar da olmalı & 4 & 11,5 \\
\hline & Kurslar başlamadan dinlendirici etkinlikler yapılmalı & 3 & 8,6 \\
\hline & Destekleme ve yetiştirme kurslarının hepsi hafta içi olmalı & 2 & 5,7 \\
\hline & Kurslarda daha farklı ve fazla materyal kullanılmalı & 2 & 5,7 \\
\hline & Hafta içi kursları başlamadan önce yemek verilmeli & 1 & 2,8 \\
\hline & Sadece belirli sayıda kurs değil talep edilen sayıda kurs olmalı & 1 & 2,8 \\
\hline & $\begin{array}{l}\text { Hafta içi kursları test ve soru çözmek yerine sosyal, sportif vb. etkinlik } \\
\text { üzerine kurulmalı }\end{array}$ & 1 & 2,8 \\
\hline Toplam & & 35 & 100 \\
\hline
\end{tabular}

Fikrim yok ile ilgili "Kurslarm daha iyi nasıl olabileceği ile ilgili şu anda aklıma herhangi bir durum gelmiyor. EÖ8-4", "Şu anda kurslarn iyileştirilmesi ile ilgili aklmma herhangi bir şey gelmiyor. Herhangi bir fikrim yok. KÖ6-1" şeklinde görüşlerini ifade etmişlerdir.

Hafta içi DYK'nın verimliliğini artırmaya yönelik, öğrenciler aynı şekilde devam etmeli ile ilgili görüşlerini, "Kurslar için ekstra bir şey yapılmasına gerek yok. Çünkü kurslar oldukça iyi. EÖ7-5", "Kurslarımız oldukça eğlenceli geçiyor. Ben kursların şimdiki halinden oldukça memnunum. KÖ5-6" şeklinde dile getirmişlerdir.

Hafta içi DYK'nın verimliliğini artırmaya yönelik öğrenciler, kurslar başlamadan önceki teneffüs uzun olmalı ile ilgili görüşlerini, "Kurs derslerine başlamadan önceki teneffüsün biraz daha uzaması güzel olurdu. KÖ5-2", "Son dersten çıkarken biraz dinlenip yemek yedikten sonra kurslar başlasa iyi olabilir. KÖ6-2" şeklinde dile getirmişlerdir. 
Hafta içi DYK'nın verimliliğini artırmaya yönelik öğrenciler, testlerin yanında oyun da olmalı ile ilgili görüşlerini, "Kurslarda testler çözülmeli ama hem oyun oynayıp hem de ders çalışılırsa, öğrenciler kursa daha çok kalır. Daha çok öğrenir ve daha çok eğlenirler. EÖ6-1", "Kurslarda son sınf öğrencisi olduğumuz için sürekli test çözüyoruz. Zaman zaman eğitici oyunlar oynanarak olumlu gelişim sağlanabilir. KÖ8-4" şeklinde dile getirmişlerdir.

Hafta içi DYK'nın verimliliğini artırmaya yönelik öğrenciler, kurslarda dinlendirici faaliyetler de olmalı ile ilgili görüşlerini, "Kurslarda test ve dersler dışında dinlendirici ve eğlendirici faaliyetler de olmalı. EÖ6-3" şeklinde dile getirmişlerdir.

Hafta içi DYK'nın verimliliğini artırmaya yönelik öğrencilerin öneriler ile ilgili kurslarda materyal kullanımını artırmak ile ilgili görüşlerini, "Kurs molaları fazla olabilir ve kurslarda öğrenmeyi kolaylaştırıcı farkl ve fazla malzemeler olmalıdır. KÖ7-1", "Kurslarda daha fazla ilgi çekici materyaller bulunmalıdır. EÖ5-5" şeklinde dile getirmişlerdir.

Destekleme ve yetiştirme kurslarının hepsi hafta içi olmalı ile ilgili “Bence tüm kurslar hafta içi olmalı çünkü cumartesi günü bazı çocuklar uyuyorlar ve kurslara gelemiyorlar. (KÖ7-3)" şeklinde görüşünü belirtmiştir.

Hafta içi kursları başlamadan önce yemek verilmeli ile ilgili "Son dersten çıktıktan sonra biraz dinlenip yemek yedikten sonra kurslar başlasa iyi olabilir. Çünkü karnım açken kurslarda yeterince öğrenemiyorum. (KÖ6-2)" şeklinde görüşünü ifade etmiştir.

Sadece belirli sayıda kurs değil talep edilen sayıda kurs olmalı ile ilgili "Sadece beş dersten kurs seçebiliyoruz. Ben ise resim, müzik, beden eğitimi, bilişim ya da istediğim dersten kurs seçmek istiyorum ama kurallar gereği seçemiyorum. KÖ7-4" şeklinde görüşünü dile getirmiştir.

Hafta içi kursları test ve soru çözmek yerine sosyal, sportif vb. etkinlik üzerine kurulmalı ile ilgili "Hafta içi kurslarında test ve soru çözmek yerine satranç, müzik ve spor derslerinin olması daha iyi olur. EÖ6-5 “ şeklinde görüşünü belirtmiştir.

Hafta içi kurslarının daha iyi nasıl olabileceğine yönelik öneriler dikkate alındığında, destekleme yetiştirme kursları ile ilgili daha önce yapılan çalışmalara benzer bulguların ortaya çıktığını söyleyebiliriz. Kursların verimli olduğu, ancak kurslar başlamadan dinlenme molalarının verilmesi, bol etkinliklerin yapılması, sanatsal ve sportif etkinliklerin de yapılması gerektiği gibi bulgular öneriler arasında yer almaktadir.

\section{Tartışma, Sonuç ve Öneriler}

$\mathrm{Bu}$ çalışmada DYK'nın hafta içi uygulamalarının öğrenci görüşleriyle değerlendirilmesi amaçlanmıştır. $\mathrm{Bu}$ amaçla elde edilen veriler analiz edilmiş, ulaşılan sonuçlar alanyazın ile karşılaştırılmıştır.

Araştırmanın birinci alt problemine ilişkin elde edilen bulgular doğrultusunda; öğrencilerin destekleme ve yetiştirme kurslarını tercih etmesindeki en önemli etkenlerin öğrencilerin, ders ve sınav başarılarını artırmak, derslerde tam olarak anlayamadığı konuları kurslar sayesinde daha iyi anlayabilmek, kurslar sayesinde konulara ilişkin yeni ve güzel bilgiler öğrenmek olduğu tespit edilmiştir. Ayrıca öğrencilerin, kurslar sayesinde konu ve ders tekrarı yapabilmeleri, kurslarda eğlenmeleri de, hafta içi destekleme ve yetiştirme kurslarını tercih etmelerindeki diğer önemli nedenler olarak ortaya çıkmıştır. Başarı, insanların hep bir adım ileri gitmesinde anahtar rol üstlenmektedir. Bu durum öğrenciler için de geçerlidir. 
Öğrencilerin okulda başarıyı tatması/tatmaması daha ileri öğrenmeler için kuvvetli bir güdüleme veya hayal kırıklığına yol açabilir (Dursun ve Dede, 2004). Buna göre kursların tercih edilmesinde ana etmenlerden birisinin kurslar sayesinde elde edilen başarı olduğu söylenebilir. Araştırmanın sonuçları, Nartgün ve Dilekçi (2016) ve Canbolat ve Köçer (2017)' in yapmış oldukları çalışmalarla örtüşmektedir. Nartgün ve Dilekçi (2016), eğitimi destekleme ve yetiştirme kurslarına ilişkin öğrenci ve öğretmen görüşleri isimli çalışmasında, destekleme ve yetiştirme kurslarına katılan öğrencilerin \%98,44'ünün ders performanslarını artırdığı sonucuna ulaşmıştır. Ünsal ve Korkmaz (2016), destekleme ve yetiştirme kurslarının öğrencilerin başarılarını artırdığı ve sınavlara katkı sağladığını vurgulamaktadır. Günümüzde, bireylerden bilgiye ulaşabilmeleri, ulaştıkları bilgileri yorumlayıp kullanabilmeleri ve mevcut bilgiler ışığında yeni bilgiler ortaya koyabilmeleri beklenmektedir (Tunçer ve Güven, 2007). Bu nedenle öğrenciler, derslerde öğrenemedikleri bilgileri öğrenmek, tekrarlar vasıtası ile bilgilerini yorumlayıp öğrenme kapasitelerini artırmak için de kursları tercih etmektedir. Ayrıca destekleme ve yetiştirme kursları, öğrencilerin dershane ve etütlere olan ihtiyacını giderme noktasında etkili olmuşlardır (Ünsal ve Korkmaz, 2016). Biber, Tuna, Polat, Altunok, ve Küçükoğlu (2017) ise öğrencilerin kursların sınav başarılarında etkili olduğunu düşünmeleri nedeniyle kursların ücretli olması durumunda da kursları tercih etmeye devam edeceklerini belirtmiştir. Ayrıca İncirci, İlğan, Sırem ve Bozkurt (2017) da yaptıkları çalışmada destekleme yetiştirme kurslarında verilen derslerin öğrenciler açısından önemli olduğu ve bu yüzden tercih edildiği sonucuna ulaşmıştır. Akkaya (2017), öğrencilerin sınavlara hazırlık sürecinde konu eksiklerini gidermek ve konuları pekiştirmek ile akademik başarılarını daha da artırmak hususlarına, destekleme ve yetiştirme kurslarını tercih etmelerindeki önemli nedenler olarak ulaşmıştır.

Araştırma sonuçları incelendiğinde, ortaokulda öğrenim gören öğrencilerin, hafta içi destekleme ve yetiştirme kurslarını, tercih etmelerindeki temel etkenin sınav başarısını ve akademik başarıyı artırmak olduğu görülmüştür. Öğrencilerin hafta içi kurslarında, ders ve sınav başarısının artmasından dolayı kursları tercih ettiklerini söyleyebiliriz.

Araştırmanın ikinci alt problemine iliş̧kin elde edilen bulgular doğrultusunda; öğrencilerin, hafta içi destekleme ve yetiştirme kurslarında görev alan öğretmenleri değerlendirmesine yönelik, öğrencilerin, kurslarda görev alan öğretmenlere ilişkin görüşlerinin çok büyük oranda olumlu olduğu ve çok az öğrenci tarafından öğretmenlere ilişkin olumsuz görüşün ifade edildiği görülmüştür. Destekleme ve yetiştirme kurslarında görev alan öğretmenlerin soru çözme tekniklerine ağırlık verdikleri, derslerde konu anlatımı yapmalarının dersin verimini artırdığı, kurslarda oyunlar sayesinde fazlasıyla eğlenebildikleri, öğrencilerin kurslar sayesinde ek çalışmalar yapabildikleri, dersleri verimli bir şekilde işledikleri en önemli olumlu sonuçlar olarak ortaya çıkmıştır. Bu durumlar, öğretmenlerin performanslarının etkili ve verimli; motivasyonlarının ise yüksek olduğu anlamına gelebilir. İleri (2014), yapmış olduğu çalışmada ulusal refahın artması ve yaşam düzeyinin iyileştirilmesinde verimliliğin önemine vurgu yapmıştır. Öğretmenlerin verimliliğini artıran unsurlardan birisi olarak motivasyon söylenebilir. Motivasyon birey, grup ve kurumları hatta üst örgütleri dahi hedefe götüren önemli bir basamaktır. Motivasyon kavramı, insanların önceden belirlenmiş bir hedefe varmak üzere kendi istek ve 
arzularıyla hareket etme süreci olarak tanımlanabilir (Ünsar, İnan ve Yürük, 2010). Öğretmenlerin de öğrencileri hedefe ulaştıran unsur olarak kendilerini görmeleri ve bu doğrultuda çalışmaları, öğrencilerin dikkatini çeken bir durum olarak karşımıza çıkmıştır. Ancak çok az da olsa, bazı öğretmenlerin isteksiz olduğu sonucu ortaya çıkmıştır. Çıkan sonuçlar incelendiğinde, hafta içi destekleme ve yetiştirme kurslarında görev alan öğretmenlerin, genel olarak öğrencileri sınavlara ve derslere hazırlama konusunda yeterli ve verimli oldukları, motivasyonlarının üst düzeyde olduğu, farklı öğretim yöntem ve teknikleri kullandıklarında dersin kalitesini artırdıkları, sınav formatına uygun olarak kursları işlemeleriyle öğrencilerin test çözme becerilerini geliştirdikleri anlaşılmaktadır. Alanyazında bu konuda yapılan bazı çalışmalarda bu sonuçları destekler bulgular karşımıza çıkmaktadır. Akkaya (2017) çalışmasında, destekleme ve yetiştirme kurslarında görev alan öğretmenlerin soru çözme tekniklerine ağırlık verdikleri, derse konu anlatımı yaparak başlamalarının dersin verimini artırdığı, öğrencilerin talep etmeleri halinde ek çalışmalar yaptıkları, dersleri verimli bir şekilde işledikleri sonuçlarına ulaşmıştır. Ünsal ve Korkmaz (2016) yaptıkları çalışmada, destekleme ve yetiştirme kurslarının öğrencinin soru çözme becerisini geliştirdiğini öğretmen görüşleriyle ortaya koymaktadır. Nartgün ve Dilekçi (2016) ise çalışmalarında öğrencilerin kurslarla ilgili olarak derse katılımı arttırdığını, konu tekrarını sağladığını ve ders notlarını yükselttiğini belirtmektedir. Ayrıca öğretmenlerin, özgüven sağlaması, daha fazla soru çözme fırsatı vermesi gibi durumları kursların öğrencilere yönelik katkısı olarak değerlendirdiklerini ifade etmektedir. Sarıca (2018) ise çalışmasında, derste öğrenilenlerin tekrar edilmesi, pekiştirilmesi, kursun ücretsiz olması ve fırsat eşitliğine katkı sağlaması, konu eksikliklerinin giderilebilmesi, anlaşılmayan konulara odaklanma, kalıcı öğrenmeye olumlu katkı, uygulamaya imkân tanıması, deneyim kazandırma, daha fazla soru çözülmesi gibi durumların kurslarla ilgili olarak öğretmenler tarafından ifade edilen görüşler bulgusuna yer vermiştir. Demir ve Narinalp (2017) yaptıkları çalışmada, kursların dersleri telafi niteliğinin olması ve öğrencilere eksik kaldıkları kısımları tamamlama fırsatı sunması, kursların öğretmen motivasyonu ve verimliliği açısından önemli bulguları arasında olduğunu ifade etmektedir. Benzer şekilde Biber vd. (2017) tarafından yapılan araştırmada da, kurslardaki yoğun soru çözme çalışmalarının, öğretmen etkililiğini sağlayan unsurlarından biri olduğu tespit edilmiştir.

Hafta içi destekleme ve yetiştirme kurslarında görev alan öğretmenlerin, ortaokulda öğrenim gören öğrenciler tarafından değerlendirilmesinin oldukça faydalı olduğu söylenebilir. Araştırmanın sonuçları incelendiğinde, öğrenci cevaplarının büyük oranda öğretmenlerin kurslarda verimli olduğu, motivasyonlarının üst düzeyde olduğu, öğretmenlerin kursları eğlenceli işlediği görülmektedir. Kurslarda tercih ve fayda unsurlarının yüksek oranda olması ile öğretmen motivasyonunun ve verimliliğinin, öğrencilere göre yüksek olması örtüşen bir sonuç olarak karşımıza çıkmaktadır.

Araştırmanın üçüncü alt problemine ilişkin elde edilen bulgular doğrultusunda; hafta içi destekleme ve yetiştirme kurslarının öğrencilere sağladığı katkılara yönelik ortaya çıkan sonuçların, hafta içi destekleme ve yetiştirme kurslarının tercih edilme nedenleri ile paralellik gösterdiği ve bu bağlamda DYK'nın öğrencilere sağladığı katkının çok büyük oranda sınav puanlarını artırdığı, akademik başarılarının gözle 
görülür seviyede yükseldiği, konuları daha iyi öğrendikleri, okul ve ders motivasyonlarının yükseldiği sonuçları ortaya çıkmıştır. Araştırma bulgularına göre tüm öğrencilere göre az ya da çok DYK'nın katkısı olduğu sonucu ortaya çıkmıştır. Araştırmanın sonuçları ilgili çalışmalarla karşılaştırıldığında da benzer sonuçların ortaya çıktığını söylemek mümkündür. Demir-Başaran ve Yıldız-Narinalp (2017) çalışmalarında kursların, öğrencilerin akademik başarılarını artırdığını belirtmişlerdir. Nartgün ve Dilekçi (2016)'ye göre destekleme ve yetiştirme kurslarına katılan öğrencilerin \%98,44'ünün ders performansları artmıştır. Ünsal ve Korkmaz (2016), destekleme ve yetiştirme kurslarının öğrencilerin başarılarını artırdığı ve sınavlara katkı sağladığını vurgulamaktadır. Yirci ve Açıkgöz (2018) çalışmasında, destekleme ve yetiştirme kurslarının en olumlu tarafının yönetici, öğretmen ve öğrenciler açısından ders tekrarı olduğunu vurgulamıştır. Bozbayındır ve Kara (2017), destekleme ve yetiştirme kurslarının en fazla okul derslerine destek olduğu, Akkaya (2017) ise öğrencilerin test çözme becerilerini geliştirdiği sonucuna ulaşmıştır. Türküresin (2018) yaptığı araştırmada, DYK'nın öğrenciler arasında fırsat eşitliği sağladığına, öğrencilere test çözme alışkanlığı kazandırdığına, onları merkezi sınavlara hazırladığına, öğrencilerin dersle ilgili eksikliklerinin kapatılmasında faydalı olduğuna ilişkin sonuçlara ulaşmıştır. Biber, Tuna, Polat, Altunok ve Küçükoğlu'nun çalışmasında (2017) öğrencilerin büyük bir çoğunluğunun, kursların kendilerini sınavlara yeterince hazırladığı görüşünde oldukları tespit edilmiştir. Göksu ve Gülcü'ye (2016) göre öğretmenlerin çoğu, kurslarda dersi hafta içinden farklı bir şekilde işleyip kurslarda soru çözme odaklı ve sınava yönelik bir yöntem takip ettiklerini ifade etmişlerdir. Ayrıca bazı öğretmenler de pek anlaşılmayan konuları derinlemesine işlemeye fırsat bulduklarını ifade etmişlerdir. Canpolat (2017) çalışmasında, öğrencilerin kursları yararlı buldukları yönler olarak: öğrenme eksikliklerinin neler olduğunu belirleme, akademik başarıyı arttırma, test çözme imkânı sağlama, pekiştirici çalışmalar, hedef belirlemeye katkı sağlama, öğretmenlerin daha fazla birebir ilgilenmesi gibi sonuçlar bildirilmektedir. Öztürk (2018) çalışmasında, öğretmen görüşlerine göre, destekleme ve yetiştirme kurslarına katılan öğrencilerin akademik başarılarını artırdığı sonucuna ulaşmıştır.

Araştırma sonuçlarına göre hafta içi destekleme ve yetiştirme kurslarının, ortaokulda öğrenim gören öğrenciler tarafından, sınav ve akademik başarılarına çok büyük oranda katkısının olduğunun düşünüldüğü görülmüştür. Öğrencilerin akademik başarısını etkileyen en önemli faktörlerin; sosyo-ekonomik durum, özyeterlik ve motivasyon olduğu yapılan araştırmalarda ortaya çıkan bir gerçektir (Sarıer, 2016). DYK'nın sosyo-ekonomik durumu iyi olmayan öğrencilere sağladığı fırsat ve bu kurslar sonucu öğrencilerin artan öz-yeterlik ve motivasyonları, bu kursların ne kadar önemli işlevleri yerine getirdiğini göstermektedir. Destekleme ve yetiştirme kurslarının hafta içi uygulamalarının, öğrenci ve öğretmen için yorucu da olsa, öğrencilere sağladığı katkılar göz önüne alındığında devam etmesi son derece önemlidir denilebilir. Kursların yorucu olmasının önüne geçecek öğrenci ve öğretmen talepleri dikkate alınarak, bu olumsuzluğun etkisi en aza indirilebilir.

Araştırmanın dördüncü alt problemine ilişkin elde edilen bulgular doğrultusunda; hafta içi destekleme ve yetiştirme kurslarının eksik yönlerinin değerlendirilmesine yönelik, öğrencilerin kurslardan çok büyük oranda memnun oldukları, sonucu ortaya çıkmıştır. Çalışmada, öğrenci görüşlerine göre, kursların 
olumlu olduğu, aksayan yönlerinin bulunmadığı görüşü hâkimdir. Bu sonuç, İncirci, İlğan, Sırem ve Bozkurt (2017) tarafından yapılan araştırma sonuçlarıyla örtüşmektedir. Bununla beraber, 7. dersten sonra yorgunluk nedeniyle konuların, test ve soruların anlaşılamaması, eğlenceli yönünün az olması, öğretmenlerin yorgunluğunun artması gibi durumların da hafta içi yapılan kurslarda yaşanan eksiklikler olduğu sonucu ortaya çıkmıştır. Araştırmanın sonuçları, ilgili çalışmalarla karşılaştırıldığında da benzer sonuçların olduğu görülmüştür. Nartgün ve Dilekçi (2016) çalışmalarında, teneffüs sürelerinin az olmasına bağlı olarak, yorgunluk yaşanması; Bozbayındır ve Kara (2017), kursların öğrencilerde yorulmaya neden olması; Sarıca (2018) ise çalışmasında kurs saatlerinin yorucu olması, zaman zaman bıkkınlık oluşturması, öğrencinin okulda uzun süre kalması, motivasyonun düşmesi, öğrenciye aşırı yük getirmesi, öğrencileri sosyal aktivitelerden uzaklaştırması gibi durumları kursların eksik yönleri olarak tespit etmişlerdir. Bununla birlikte Yirci ve Açıkgöz (2018) çalışmasında, destekleme ve yetiştirme kurslarına ilişkin öğrencilerin doküman eksikliği, sıkılganlık, hafta içi olması, aileyle vakit geçirememe ve sosyal olarak kısıtlanma yaşadıklarını ve bu durumu, kursların olumsuz yönleri olarak gördüklerini ortaya çıkarmıştır. Türküresin (2018), çalışmasında öğretmenlerin görüşleri doğrultusunda, destekleme ve yetiştirme kurslarının hafta içi yapılması halinde öğrencilerin motivasyonunu düşürdüğü sonucuna ulaşmıştır. DemirBaşaran ve Yıldız-Narinalp (2017), sınavlara hazırlanan öğrencilerin bir dersten çıkıp başka bir derse girme telaşıyla belirli bir süre sonra bıkkınlık ve yorgunluk yaşadıkları ve disiplin sorunlarının varlığına da vurgu yapmıştır. Hafta içi 35 saat derse ek olarak kurs almalarının, çoğu öğrencinin haftanın yedi günü de okula devam etmelerinin onlar için yorucu olduğunu çalışmasında ifade etmiştir.

Araştırma sonuçlarına göre hafta içi destekleme ve yetiştirme kurslarının, eksik yönleri için, öğrencilerde yedi saat dersin sonrasında, 80 dakika kurs yapılmasının yorgunluk, sosyal etkinlikler için gereken zamanın azalması ve bu durumun sonucunda okul motivasyonunun düşmesi gibi durumlar olduğunu söylemek mümkündür.

Araştırmanın beşinci alt problemine ilişkin elde edilen bulgular doğrultusunda; hafta içi destekleme ve yetiştirme kurslarının verimliliğini artırmaya yönelik öğrenci önerileri olarak: kursların verimli olduğu ve aynı şekilde devam etmesi gerektiği, teneffüs sürelerinin uzun olması gerektiği, testlerle beraber oyunların da olması gerektiği, dinlendirici etkinliklere yer verilmesi gerektiği ifade edilmiştir. Ayrıca, hafta içi kursları başlamadan yemek verilmesi, belirli sayıda değil talep edilen sayıda kurs olması, materyal zenginliğinin artırılması gereği gibi sonuçlar ortaya çıkmıştır. Araştırmanın sonuçları ilgili çalışmalarla karşılaştırıldığında benzer sonuçlara rastlamak mümkündür. Akkaya (2017) çalışmasında, kurslar hazırlanırken haftanın bazı gün ya da saatlerinde sosyal veya sportif faaliyetlerin programlara eklenerek kurslarda bu programin uygulanması ile öğrencinin sınav stresinden uzaklaşabileceği, böylelikle sınava daha iyi hazırlanabileceği ve motivasyonunun yükselebileceğini dile getirmiştir. Haritalar, eğitim setleri ve diğer çeşitli eğitim-öğretim materyallerine ilişkin eksiklerin giderilmesinin ve zenginleştirilmesinin, öğrencilerin derse olan ilgisini ve öğrenmelerin motivasyonunu artırabileceği; akademik başarının da yükselmesini sağlayabileceği (Bozbayındır ve Kara, 2017; Canpolat ve Köçer, 2017; Göksu ve 
Gülcü, 2016; Ünsal ve Korkmaz, 2016) dile getirilen diğer hususlardır. Öğrencilerin hafta içi beslenme sorunlarının çözülmesi (Bozbayındır ve Kara, 2017), kurslarda sınava yönelik derslerle birlikte öğrencilerin genel yetenek ve kültürlerini geliştirecek derslere (Resim, Müzik vb.) ve etkinliklere de yer verilmesi gerektiği gibi durumlar alanyazında yer alan benzer öneriler olarak karşımıza çıkmaktadır. Gök ve Şekerci (2017), materyal eksikliğinin çeşitli sorunları beraberinde getirmesine vurgu yapmaktadır. Buna paralel olarak Ünsal ve Korkmaz (2016), yine materyal kullanım boyutunda doküman eksikliğinin giderilmesini önermektedir. Demir-Başaran ve Yıldız-Narinalp (2017), kurslara sportif ve kültürel etkinliklerin eklenebileceğini araştırmalarında belirtmiştir. Nartgün ve Dilekçi (2018) ise destekleme ve yetiştirme kurslarındaki teneffüs sürelerinin öğrencilerin ihtiyaçlarını tam anlamıyla karşılayabilecekleri makul sürelere çekilmesi önerisinde bulunmuştur. Sarıca (2018), çalışmasında kurs saatlerinin iyi planlanması, dersler için daha fazla kaynak sağlanması, ulaşım ve beslenme sorunu çözülmesi, okul ders saatlerinin azaltılması, kurslarla ilgili öğrencilere rehberlik yapılması önerilerinde bulunmuş ve bu önerilerin uygulanması durumunda kurslarda verimliliğin artacağını ifade etmiştir. İncirci vd. (2018) çalışmalarında, destekleme yetiştirme kurslarında verilen derslerin öğrenciler açısından önemli olduğunu ancak öğrencileri ders çalışmaya güdülemede yetersiz kaldığı sonucuna ulaşmıştır. Kurslarda öğrencileri ders çalışmaya güdüleyecek gerekli ortamın oluşturulmasının sağlanabileceği önerisinde bulunmuştur.

Araştırma sonuçlarına göre hafta içi destekleme ve yetiştirme kurslarında, verimliliği artırabilmek için teneffüs sürelerinin uzatılması, sosyal ve sportif etkinliklerin artırılması, materyallerin zenginleştirilmesi, kurs sayısının artırılması ve kursların başlamasından hemen önce beslenme sorunlarının giderilmesi gibi durumların çözülmesinin öğrenci önerileri olarak ortaya çıtığ görülmüusstür.

Hafta içi destekleme ve yetiştirme kurslarının değerlendirilmesine yönelik, araştırmaya katılan öğrencilerin büyük çoğunluğunun olumlu düşüncelere sahip olduğu görülmüştür. DYK'ların önemli ölçüde başarılı olduğu ve akademik başarıda olumlu sonuçlar doğurduğu anlaşılmıştır. Bununla birlikte daha iyi bir düzeye getirilmesi ve mevcut eksikliklerinin giderilmesi için, zorunlu ve seçmeli ders saatlerini kapsayan haftalık ders çizelgesi, eğitimi destekleme ve yetiştirme kurslarındaki ders saatleri göz önüne alınarak yeniden düzenlenebilir. Okulda geçirilen süre uzadıkça, öğrencilerin bazı disiplin sorunları ortaya çıkardı̆̆ı, bunun nedenleri olarak okulda sınıf ortamında dokuz saat kalan öğrencilerin sosyal aktivitelere ayıracak zamanlarının daralması ve öğrencilerin enerjilerini atamamaları gibi durumlar ifade edilmektedir. Öğrencilerin, hafta içi kurslarında yaşamış olduğu yorgunluk, sosyalleşme sorunu ve enerjilerini atamamaları teneffüs vakitlerinde bazı disiplin sorunlarını meydana getirmektedir. Kursların yanında eğlendirici etkinlikler de uygulanabilir olduğunda bu tarz sorunların önüne geçilebileceği söylenebilir. Kurslarda öğrencilerin, ilgi ve motivasyonun sürekliliğini devam ettirmek amacıyla, sosyal faaliyetlere (futbol, voleybol, basketbol, satranç, gezi, yarışma, dijital oyun vb.) yer verilebilir. Eğitimi destekleme ve yetiştirme kurslarındaki teneffüs süreleri öğrencilerin ihtiyaçlarını karşılayabilecekleri süreler olarak düzenlenebilir. Hafta içi destekleme ve yetiştirme kurslarının uygulamadaki sorunlarından birisi de beslenme sorunudur. Bu doğrultuda aile ya da okul yönetimi tarafından önlemler alınabilir. 
Destekleme ve yetiştirme kurslarında dersler seçilirken, öğrencilerin talepleri dikkate alınmalıdır. Çalışmanın sınırlılıklarından yola çıkarak şu önerilerde bulunulabilir: Yapılacak çalışmalarda, öğretmenlerin ve yöneticilerin de eğitimi destekleme ve yetiştirme kurslarının hafta içi uygulamasına yönelik görüşleri alınabilir. Kursların hafta sonu uygulamaları da tüm yönleriyle çalışılabilir. Kurslar ile ilgili velilerin de görüş ve önerileri alınabilir. Hafta içi destekleme ve yetiştirme kurslarının hafta sonu yapılan kurslarla karşılaştırması yapılabilir.

\section{Kaynakça}

Akkaya, A. (2017). Destekleme ve yetiştirme kurslarmın öğrenci görüşlerine göre değerlendirilmesi. (Yayınlanmamış Yüksek Lisans Tezi). Ahi Evran Üniversitesi Sosyal Bilimler Enstitüsü, Kırşehir.

Aküzüm, C. ve Saraçoğlu, M. (2018). Ortaokul öğretmenlerinin destekleme ve yetiştirme kurslarına yönelik tutumlarının incelenmesi. Turkish Jourmal of Educational Studies, 5(2), 97-121. https:/ / doi.org/10.33907/turkjes.423152

Atabay, S. (2019). Dershanelerin eğitim sistemindeki yeri, işlevi ve dönüştürülme süreci. https:/ / tedmem.org/mem-notlari/gorus/dershanelerin-egitimsistemindeki-yeri-islevi-ve-donusturulme-sureci adresinden alınmıştır. (Erişim tarihi: 14 Mart 2020).

Biber, A. Ç., Tuna, A., Polat, A. C., Altunok, F. ve Küçükoğlu, U. (2017). Ortaokullarda uygulanan destekleme ve yetiştirme kurslarına dair öğrenci görüşleri. Bayburt Eğitim Fakültesi Dergisi, 12(23), 103-119.

Bozbayındır, F. ve Kara, M. (2017). Destekleme ve yetiştirme kurslarında karşılaşılan sorunlar ve öğretmen görüşleri temelinde çözüm önerileri. Sakarya University Journal of Education, 7(2), 324-349. https:/ / doi.org/10.19126/suje.335982

Büyüköztürk, Ş. (2016). Sinavlar üzerine düşünceler. Kalem Eğitim ve İnsan Bilimleri Dergisi 6(2), 345-356. https:/ / doi.org/10.23863/ kalem.2017.64

Büyüköztürk, Ş., Kılıç Çakmak, E., Akgün, Ö.E., Karadeniz, Ş. ve Demirel, F. (2016). Bilimsel araştırma yöntemleri. Ankara: Pegem Akademi. https:// doi.org/10.14527/9789944919289

Canöz, T. (2014). Türkiye' de 2003- 2013 yılları arasında uygulanan eğitim politikalarının eğitimde firsat eşitliği bakımından analizi. (Yayınlanmamış Yüksek Lisans Tezi). Fatih Üniversitesi Sosyal Bilimler Enstitüsü, İstanbul.

Canpolat, U. ve Köçer, M. (2017). Destekleme ve yetiştirme kurslarının TEOG bağlamında sosyal bilgiler öğretmenlerinin görüşlerine dayalı olarak incelenmesi. AJESI - Anadolu Journal of Educational Sciences International, 7(1), 123-154.

Davis, D. and Sorrell, J. (1995). Mastery Learning in Public Schools: Educational psychology interactive. Valdosta, GA: Valdosta State University. http:/ / www.edpsycinteractive.org/files/mastlear.html (Erişim tarihi: 14 Mart 2020).

Demir Başaran, S. ve Yıldız Narinalp, N. (2017). Türkiye'de ortaokullarda uygulanan destekleme ve yetiştirme kurslarına ilişkin öğretmen görüşleri. International Journal of Eurasia Social Sciences, 8(29), 1152-1173.

Dinçer, M. A. ve Kolaşin, G. U. (2009). Türkiye'de öğrenci başarısızlığında eşitsizliğin belirleyicileri. Eğitim reformu girişimi (ERG), İstanbul: Sabancı Üniversitesi. 
Dursun, Ş. ve Dede, Y. (2004). Öğrencilerin matematikte başarısını etkileyen faktörler: Matematik öğretmenlerinin görüşleri bakımından. Gü, Gazi Eğitim Fakültesi Dergisi, 24(2), 217-230.

Erdoğan, K. (2013). Eğitim kurumlarında gerçekleştirilen ders dişı etkinliklerin sınıflandırılmasına yönelik bir öneri. Uluslararası Türkçe Edebiyat Kültür Eğitim Dergisi, 2(2), 336-353.

Ersoy, A. F. (2017). Fenomenoloji. Saban, A., Ersoy, A. (Ed.). Eğitimde nitel araştırma desenleri içinde (81-134). Ankara: Anı Yayıncılık.

Ertürk, S. (1997). Ĕ̆itimde program geliştirme. Ankara: Meteksan A.Ş.

Gök, R. ve Şekerci, R. (2017). Yetiştirme kurslarının halk eğitimi merkezlerine devredilmesine ilişkin paydaş görüşleri. Mehmet Akif Ersoy Üniversitesi Eğitim Fakültesi Dergisi, 44, 276-296. https:/ / doi.org/10.21764/maeuefd.296643

Göksu, İ. ve Gülcü, A. (2016). Ortaokul ve liselerde uygulanan destekleme kurslarıyla ilgili öğretmen görüşleri. Bayburt Eğitim Fakültesi Dergisi, 11, 154-171.

İçer, M. M. (1997). Türkiye'de eğitim sisteminin genel amaçları ve temel eğitim ilkelerinin değerlendirilmesi. (Yayınlanmamış yüksek lisans tezi). İnönü Üniversitesi Sosyal Bilimler Enstitüsü, Malatya.

İleri, Y. (2014). Verimlilik, verimlilik ile ilgili kavramlar ve işletmeler açısından verimliliğin önemi. Selçuk Üniversitesi Sosyal Bilimler Meslek Yüksekokulu Dergisi, 1(2) , 9-24.

İncirci, A., İlğan, A., Sirem, Ö. ve Bozkurt, S. (2017). Ortaöğretim destekleme ve yetiştirme kurslarına ilişkin öğrenci görüşleri. Mehmet Akif Ersoy Üniversitesi Ĕ̆itim Fakültesi Dergisi, 42, 50-68. https:/ / doi.org/10.21764/efd.84291

Kaya, Z. (Ed.). (2012). Öğrenme ve öğretme. Ankara: Pegem Akademi.

Kıral, B. ve Kıral, E. (2009). Japonya ilköğretim sistemi ve Türkiye ilköğretim sisteminin karşılaştırılması. Dicle Üniversitesi Ziya Gökalp Ĕ̆itim Fakültesi Dergisi, 12, 53-65.

Mc Kisney Company. (2007). How the World's Best-Performing School Systems Come Out on Top. Londra: McKinsey and Company.

MEB. (2014). Milli Ĕ̆itim Bakanlı̆̆ı Örgün ve Yaygın Eğitimi Destekleme ve Yetiştirme Kurslarn Yönergesi,

http:/ / mevzuat.meb.gov.tr/html/orgundestek_1/yonerge.pdf (Erişim tarihi: 14 Mart 2020).

MEB. (2015). Milli Eğitim Bakanlı̆̆ı Özel Öğretim Kurumları Yönetmeliğinde Değgişiklik Yapilmasina Dair Yönetmelik,

http:/ / www.resmigazete.gov.tr/main.aspx?home=http:/ / www.resmigazete. gov.tr/eskiler/2015/08/20150808.htm\&main=http:/ / www.resmigazete.gov.t r/eskiler/2015/08/20150808.htm (Erişim tarihi: 14 Mart 2020).

MEB. (2016a). Örgün ve yaygın eğitimi destekleme ve yetiştirme kursları tanıtım kitapçı̆̆ı, http:/ /odsgm.meb.gov.tr/meb_iys_dosyalar/2016_10/21045232_tanitim_kita pcigi_dyk.pdf. (Erişim tarihi: 14 Mart 2020).

MEB, (1973). Millî eğitim temel kanunu. Ankara: MEB Yayınları.

MEB, (2018). Destekleme ve Yetiştirme Kursları E-Kılavuzu. (17 Mayıs 2019 tarihinde www.meb.gov.tr/meb_iys_dosyalar/2018_09/05111501_DYK_e_kilavuz.pdf adresinden alınmıştır).

Mercik, V. (2015). Ĕ̆itimde firsat eşitliği, toplumsal genel başarı ve adalet ilişkisi: PISA Projesi kapsamında Finlandiya ve Türkiye deneyimlerinin karşılaştırılması. 
(Yayınlanmamış Yüksek Lisans Tezi). Balıkesir Üniversitesi Sosyal Bilimler Enstitüsü, Balıkesir.

Nartgün, Ş. S. ve Dilekçi, Ü. (2016). Eğitimi destekleme ve yetiştirme kurslarına ilişkin öğrenci ve öğretmen görüşleri. Kuram ve Uygulamada Ĕ̆itim Yönetimi, 22(4), 537-564.

Öztürk, O. (2018). Destekleme ve yetiştirme kurslarında görev alan öğretmenler ile görev almayan ögretmenlerin mesleki doyum düzeyleri. (Yayımlanmış Yüksek Lisans Tezi). Çanakkale On Sekiz Mart Üniversitesi, Eğitim Bilimleri Enstitüsü, Çanakkale.

Sarıca, R. (2018). Destekleme ve yetiştirme kurslarına (DYK) yönelik öğretmen görüşleri. Milli Eğitim, 48(221), 91-122.

Sarıer, Y. (2016). Türkiye'de öğrencilerin akademik başarısını etkileyen faktörler: Bir meta-analiz çalışması. Hacettepe Üniversitesi Eğitim Fakültesi Dergisi, 31(3), 1-19. https:// doi.org/10.16986/HUJE.2016015868

Şahin, C. ve Gül, K. (2017). Yetiştirme kursuna devam eden ve etmeyen ortaokul öğrencilerinin İngilizce ders başarısı ile okul tükenmişliği ilişkisi. Uluslararası Ĕ̈itim Bilimleri Dergisi (Inesjournal), 4(12), 216-229. https:/ / doi.org/10.16991/INESJOURNAL.1466

TDK. Güncel Türkçe Sözlük. www.tdk.gov.tr (Erişim tarihi: 13 Mart 2020).

Tunçer, B. K. ve Güven, B. (2007). Öğrenme stratejileri kullanımının öğrencilerin akademik başarıları, hatırda tutma düzeyleri ve derse ilişkin tutumları üzerinde etkisi. Yüzüncü Yıl Üniversitesi, Eğitim Fakültesi Dergisi, 4(2), 1-20.

Türküresin, E. H. (2018). Destekleme ve yetiştirme kurslarının öğretmen ve öğrenci görüşlerine göre incelenmesi. Kütahya İli Örneği. Adnan Menderes Üniversitesi Ĕ̆itim Fakültesi Ĕ̆itim Bilimleri Dergisi, 9(2), 73-85.

Uğurlu, F. ve Aylar, F. (2017). Destekleme ve yetiştirme kurslarına yönelik öğretmen öz alg1 ölçeğinin geliştirilmesi: Geçerlik ve güvenirlik çalışması. Gazi Eğitim Bilimleri Dergisi, 3(1), 28-43.

Ünsal, S. ve Korkmaz, F. (2016). Destekleme ve yetiştirme kurslarının işlevlerine ilişkin öğretmen görüşlerinin incelenmesi. Kahraman Maraş Sütçü İmam Üniversitesi Sosyal Bilimler Dergisi, 13(2), 87-118.

Ünsar, A. S., İnan, A. ve Yürük, P. (2010). Çalışma hayatında motivasyon ve kişiyi motive eden faktörler: Bir alan araştırması. Trakya Üniversitesi Sosyal Bilimler Dergisi, 12(1), 248-262.

Yıldırım, A. ve Şimşek, H. (2018). Sosyal bilimlerde nitel araştırma yöntemleri. Ankara: Seçkin.

Yılmaz, M. (2009). Öğrenme ve bilgi ilişkisi. Gü, Gazi Eğitim Fakültesi Dergisi, 29(1), 172-191.

Yirci, R. ve Açıkgöz, M. Y. (2018). 5. Uluslararası eğitim bilimleri sempozyumu 25-26-

27 Ekim 2018. V. Uluslararası eğitim bilimleri sempozyumu tam metin kitabı (s. 169-186).

İstanbul: Asos Yayınevi. 


\section{Summary}

\section{Introduction}

The learning levels of students may vary due to individual characteristics, the economic condition of the country, technological structures, policies, educational programs, teachers, families etc. Because of these factors, which are effective on learning, reinforcing trainings are needed to ensure incomplete learning to be completed if learning is not at the desired level. Resulting from that, a placement examination to an upper educational institution in the following of the primary school education, namely the High School Entrance Exam, which is a national examination in Turkey that students compete with each other and want to be much more successful, increases the demand for these additional trainings. For this reason, students are tend to participate in tutoring, private courses and weekend courses in schools in order to both be successful in school exams and prepare themselves well for national exams (Uğurlu and Aylar, 2017). In our country, the low economic situation of some students' families and their perspectives on education limit their children's opportunities to get supplementary trainings. This situation adversely affects equality of educational opportunity (Mercik, 2015). In order to eliminate this negative situation regarding the equality of educational opportunity, the Ministry of National Education has brought the practice of formal and non-formal educational Supporting and Training Courses into action since the 2014-2015 academic year in order to provide students that still study at a middle or high school and individuals graduated from a high school with the equal of education opportunities on preparing national examinations (Milli Eğitim Bakanlığı Örgün ve Yaygın Eğitimi Destekleme ve Yetiştirme Kursları Yönergesi [MEB], 2014: madde 1).

It has been observed that no enough studies in the literature on the Supporting and Training Courses, known with its positive academic, psychological, economic and sociological contributions to students (Nartgün and Dilekçi, 2016) has been found. Therefore, it is crucial to investigate this practice, which is highly desired by students, which affects students, parents and teachers with its results, and which is quite new for the education system. It is assumed that revealing the problematic points and issues experienced during these courses increase the efficiency and quality of the courses. In this context, it is aimed to examine the opinions of the middle school students who participated in the Supporting and Training Courses on weekdays.

\section{Method}

The study was designed as a qualitative research method. The descriptive phenomenology design among the qualitative research methods was used in the study. The participants of the study consisted of 35 students out of 94 students of fifth, sixth, seventh and eighth grades studying at a middle school located in the center of Düzce Province, Turkey and attending to the Support and Training Courses during the 2018-2019 academic year. The research group was determined by the methods of criterion sampling and maximum diversity sampling. In the study, semistructured interview forms developed by the researcher were conducted. For the data analysis, the technique of "content analysis", which is one of the qualitative analysis methods, was used. 


\section{Results}

As a result of the research, the reasons why the students preferred the Support and Training Courses were determined as increasing the success on courses and exams, reviewing subjects and courses, getting much more information on lessons. It was also concluded that in terms of teacher effectiveness, teacher motivation was at high level and the teachers made the courses fun; in terms of the advantages of the courses for the students, they got better grades from the exams and the success in courses increased; however, regarding the disadvantages of the courses, the courses were mostly productive and no observable shortcomings were found. Suggestions for the efficiency of the courses included that the courses should continue in the same way, and that it is necessary to have a lunch break or relaxing activities before the courses start.

\section{Discussion}

When the results of the study were examined, it was reported that the main reason of the preference of participating in the Supporting and Training Courses on weekdays of the students studying in the middle schools was to get prepared for the exams and increase their academic success. It may be noted that the previously achieved objectives of the students have an effect on the course preference. The opportunity provided by the Supporting and Training Courses to students with poor socioeconomic status and therefore the increased self-efficacy and motivation of the students show how these courses perform important functions. It is of uttermost importance that the Supporting and Training Courses should continue even if they are tiring for both students and teachers. At the end of the research, it was suggested to extend the break time, give place to social and sporting activities, enrich the materials, increase the number of courses and eliminate nutritional problems just before the start of the courses with the aim of increasing the effectiveness of the courses.

\section{Pedagogical Implications}

In the current study, how the process of the practice on weekdays of the Supporting and Training Courses taking place in the middle schools affiliated to the Ministry of National Education and concerning millions of students in our country was and which problems were experienced during this process were detected through the opinions of the students. It is thought that revealing the political points and issues experienced during the courses and making suggestions to improve the efficiency and quality of these courses contribute to the field.

\section{Araştırmanın Etik Taahhüt Metni}

Yapılan bu çalışmada bilimsel, etik ve alıntı kurallarına uyulduğu; toplanan veriler üzerinde herhangi bir tahrifatın yapılmadı̆̆ı, karşılaşılacak tüm etik ihlallerde "Cumhuriyet Uluslararası Eğitim Dergisi ve Editörünün" hiçbir sorumluluğunun olmadığı, tüm sorumluluğun Sorumlu Yazara ait olduğu ve bu çalışmanın herhangi başka bir akademik yayın ortamına değerlendirme için gönderilmemiş olduğu sorumlu yazar tarafından taahhüt edilmiştir. 


\section{Authors' Biodata/ Yazar Bilgileri}

Ender KAZAK Düzce Üniversitesi Eğitim Fakültesi Eğitim Yönetimi ve Denetimi Anabilim Dalında Dr. Öğr. Ü. olarak görev yapmaktadır. Örgütsel adalet, denetim, kuşaklararası öğrenme ve örgütsel imaj konularında çalışmalar yürütmüştür. Yalnızlık, örgütsel iklim, iletişim iklimi, sendikal yanlılık, angarya, etkili okul ve etkili müdür konularında çalışmaları devam etmektedir.

Ender Kazak is working as an assistant professor in the Department of Educational Administration and Supervision, Faculty of Education, Düzce University. He has conducted studies on organizational justice, supervision, intergenerational learning and organizational image. His work continues on loneliness, organizational climate, communication climate, union bias, drudgery, effective school and effective principal.

Ahmet KESKİN Düzce Üniversitesi Eğitim Fakültesi Eğitim Yönetimi ve Denetimi Anabilim Dalında yüksek lisans eğitimine devam etmektedir. Düzce İl Milli Eğitim Müdürlüğünde öğretmen olarak görev yapmaktadır.

Ahmet Keskin continues his master's education in the Department of Educational Administration and Supervision of Düzce University, Faculty of Education. He is working as a teacher affiliated with Düzce Provincial Directorate of National Education. 